\title{
Floral buds retention affects the seed production and quality of okra varieties under agro-climatic conditions of Peshawar-Pakistan
}

\author{
Muhammad Affan Khan* and Abdur Rab \\ Department of Horticulture, The University of Agriculture Peshawar, Khyber Pakhtunkhwa-Pakistan \\ *Corresponding author's email:ffnkhan@gmail.com \\ Citation \\ Muhammad Affan Khan and Abdur Rab. Floral buds retention affects the seed production and quality of okra \\ varieties under agro-climatic conditions of Peshawar-Pakistan. Pure and Applied Biology. Vol. 8, Issue 1, \\ pp900-909. http://dx.doi.org/10.19045/bspab.2019.80032
}

\begin{tabular}{llll}
\hline \hline Received: 31/12/2018 & Revised: 08/03/2019 & Accepted: 11/03/2019 & Online First: 14/03/2019 \\
\hline \hline
\end{tabular}

\section{Abstract}

The influence of floral buds on growth, seed yield and quality of okra were studied at the Agricultural University; Peshawar during spring seasons (2012-13) using Randomized Complete Block Design with 3 replications. Five okra varieties viz. Sabz Pari, Arka Anamika, Pusa Sawani, Punjab Selection and Green Star were evaluated by retaining 8, 11, 14, 17 and 20 floral buds for seed production. Maximum plant height $(131.65 \mathrm{~cm})$, number of branches plant per plant (2.04), seeds per pod (65.30), seed weight per pod (4.29 g) and seed yield (2.37 $\mathrm{t} \mathrm{ha}^{-1}$ ) were recorded in variety Arka Anamika. However, the maximum leaves per plant (39.88) and 100 seed weight (7.55 g) were recorded in Sabz Pari and Pusa Sawani respectively. Retention of 8 floral buds resulted in the maximum plant height $(128 \mathrm{~cm})$, number of branches per plant (2.16), seeds per pod (69.72), seed weight per pod (4.29 g), but the minimum seed yield $\left(1.51 \mathrm{t} \mathrm{ha}^{-1}\right)$. Highest seed yield $\left(2.77 \mathrm{t} \mathrm{ha}^{-1}\right)$ as well hard seed $(26.77 \%)$ were recorded with 20 floral buds retention. The varieties and floral buds interaction revealed significantly higher plant height $(134.47 \mathrm{~cm})$ and seed yield $\left(3.69 \mathrm{t} \mathrm{ha}^{-1}\right)$ in variety Arka Anamika with retaining 8 and 20 floral buds respectively. By contrast, the minimum plant height $(123.67 \mathrm{~cm})$ in Sabz Pari and seed yield (1.39 $\left.\mathrm{t} \mathrm{ha}^{-1}\right)$ in Punjab Selection were recorded with 20 and 8 floral buds respectively. Retaining 14 to 17 floral buds may contribute to the reasonable economic okra seed yield.

Keywords: Floral buds; Okra varieties; Seed production; Seed quality

\section{Introduction}

Okra is a tropical to subtropical crop and popular summer vegetable in many countries around the world [1]. Okra is desired for its young green pods, which are cooked along with the immature seeds. 100 $\mathrm{g}$ of fresh okra pods contain protein $2.1 \mathrm{~g}$, carbohydrates $8.2 \mathrm{~g}$, fat $0.2 \mathrm{~g}$, fiber $1.7 \mathrm{~g}$, potassium $103 \mathrm{mg}$, phosphorus $90 \mathrm{mg}$, calcium $84 \mathrm{mg}$, magnesium $53 \mathrm{mg}$, iron $0.35 \mathrm{mg}$, sulphur $30 \mathrm{mg}$, copper $0.19 \mathrm{mg}$, sodium $6.9 \mathrm{mg}$, nicotinic acid $0.6 \mathrm{mg}$, vitamin C $13 \mathrm{mg}$, riboflavin $0.1 \mathrm{mg}$, niacin $0.6 \mathrm{mg}$, thiamine $0.07 \mathrm{mg}$, ascorbic acid $47.0 \mathrm{mg}$, oxalic acid $8 \mathrm{mg}$ and $\beta$-carotene $185 \mu \mathrm{g}$ [2]. The seeds of okra contain $40 \%$ oil contents which can be an alternative source of edible oil, whereas the mucilage of young pods is rich in carbohydrates as well as pectin and used as a thickener in food industries [3]. The crude fiber present in okra stem can be used in paper industry 
and preparing ropes [4]. There have been a considerable number of okra varieties developed and introduced in Pakistan, which differ greatly in their fresh pods yield and seed production potentials [5]. Okra growth and yield performance depends on several factors such as seed quality, nutrition, climatic conditions and cultural practices as well as differences in genetic potentials [6-11]. Quality okra seed production on domestic level is an essential component for sustainable okra cultivation and minimizing reliance on expensive imported seed. Generally, the seed is either produced by local farmers or supplied by unreliable sources [12]. The okra plant starts flowering after developing 5 to 8 leaves and continue to flower and produce fruit throughout the season [13]. For okra seed production, the fruit must mature on the plant. The maturing fruits may, however, act as powerful sinks and divert the photoassimilate distribution from plant growth and flower formation [14]. By contrast, removing the immature pods may promote the source strength [15] and enhance vegetative growth [16]. Thus, harvesting the young pods regularly may increase the total number of pods formed [17]. The commercial production of okra seed is further restricted as the farmers generally pick green fruits and allow only a small number of pods to mature for seed production and hence the seed yield is minimized [18]. Thus, fruit load management may significantly enhance the seed quality [19-21].

Another major problem in okra seed production is the hardseedeness observed in most Hibiscus species including okra [22]. The hardseeds are characterized by thick seed coat, which may result in delay or failure to germinate [23].

Keeping in view the genetic differences among the okra varieties, and the influence of floral buds on subsequent pods formation as well as its influence on seed production and quality, the present experiment was conducted to ascertain the influence of floral buds on the seed yield and hardseed percentage of commonly grown okra varieties.

\section{Materials and methods}

The research study to investigate the influence of floral buds retention on the seed production and quality of various okra varieties was carried out at the Horticultural Farm, The University of Agriculture, Peshawar, Pakistan during spring seasons of the years 2012-2013. The experimental site is situated at $34^{\circ} \mathrm{N}, 71.3^{\circ} \mathrm{E}$ and an altitude of 450 meters above sea level. The soil of the experimental field was silty clay loam, low in nitrogen (0.02-0.035\%), low in organic matter (0.6-1\%) and alkaline in nature ( $\mathrm{pH}$ 8.2-8.3). Five okra varieties viz. Sabz Pari, Arka Anamika, Pusa Sawani, Punjab Selection and Green Star were used in the experiment. The floral buds management was established by allowing 8 , $11,14,17$ and 20 floral buds to develop as pods in the selected plants and the excess were removed. The recommended fertilizer dose for okra crop (120-150-120) was supplied in the form of Urea, Single Super Phosphate and Sulphate of Potash. The recommended dose of Farm Yard Manure was applied before soil preparation. All routine cultural practices like weeding, hoeing and pesticides application were kept uniform and constant.

\section{Attributes studied}

\section{Plant height (cm)}

Ten plants were randomly selected in each replication, and their height measured from the ground level to the top of the main stem, with the help of a measuring tape and expressed in centimeters.

\section{Number of branches plant ${ }^{-1}$}

The branches emerging from main stem were counted in 10 plants at random and averaged to represent the number of branches plant ${ }^{-1}$.

\section{Number of leaves plant ${ }^{-1}$}

The numbers of leaves were counted in 10 plants at random and the average number of leaves per plant was calculated for each treatment and replication. 


\section{Number of seeds pod $^{-1}$}

The pods were removed from selected plants and the number of seeds was calculated in each pod. The total number of seeds was divided by the number of pods taken for seed counted in each treatment and presented as average number of seeds per pod.

Seed weight $\operatorname{pod}^{-1}(\mathrm{~g})$

The seeds obtained from five randomly selected pods from each plant under observation per replication were weighed separately and the average of seed weight per pod was calculated and expressed in grams.

\section{Hundred seed weight (g)}

The pods from each replication were harvested and threshed separately. Hundred seeds were randomly taken from each treatment and replication and the average weight was recorded and expressed in grams.

\section{Seed yield (tons ha-1)}

The seed yield of ten plants selected for data recording were added to the seed yield of net experimental plot area to calculate the seed yield per hectare (expressed in tons $\mathrm{ha}^{-1}$ ) according to the following formula: Seed Yield (tons $\mathrm{ha}^{-1}$ ) $=$ Yield per plot $(\mathrm{kg}) /$ Area of plot $\left(\mathrm{m}^{2}\right) \times 10000$

\section{Hard seed percentage}

The hard seed percentage was estimated by placing 100 seeds of each treatment in seed germination trays containing moist tissue paper. The seeds were allowed to stay in germination trays for 10 days at $25^{\circ} \mathrm{C}$. The tissue in the trays was moistened periodically to retain it in a moist condition. The seed germination was observed on daily basis and seeds with radical protrusion through the coat were regarded as germinated. The germinated seeds were removed and the percentage of seeds that failed to germinate during 10 days were considered as hard seed [24].

\section{Experimental design}

Studies were carried out in spring season of the years 2012-13 using Randomized Complete Block Design with three replications. The treatments included five okra varieties i.e. Sabz Pari, Arka Anamika, Pusa Sawani, Punjab Selection and Green Star, planted at five crop load levels i.e. 8, $11,14,17$ and 20 floral buds to develop as mature pods for seed extraction. The row to row and plant to plant spacing was 60 and $40 \mathrm{~cm}$ respectively. The varieties were assigned to main plots and the crop load levels were kept in the subplots.

\section{Statistical analysis}

The data were analyzed using software Stastix 8.1. Main and interaction effects were compared using LSD test at 0.05 level of probability, when the F-values were significant and the means were separated [25].

\section{Results and discussion \\ Plant height (cm)}

Okra varieties varied significantly in plant height and maximum plant height (131.65 $\mathrm{cm})$ was recorded in Arka Anamika followed by Green Star $(128.71 \mathrm{~cm})$. Pusa Swani, Punjab Selection and Sabz Pari had plant heights of $124.29 \mathrm{~cm}, 122.73 \mathrm{~cm}$ and $118.99 \mathrm{~cm}$ respectively (Table 1 ). The least mean plant height of okra varieties (120.26 $\mathrm{cm}$ ) was recorded with 20 floral buds retention, which increased to 125.23, 126.11, 126.68 and $128.07 \mathrm{~cm}$ with decreasing the number of floral buds to 17 , 14, 11 and 8 floral buds respectively (Table 1 ). The interaction of varieties and floral buds also significantly affected the plant height of okra. The plant height increased significantly with decreasing the number floral buds for seed production. The minimum plant height in Sabz Pari (109.9 $\mathrm{cm})$, Arka Anamika (129 cm), Pusa Sawani $(120.6 \mathrm{~cm})$, Punjab Selection $(116.80 \mathrm{~cm})$ and Green Star $(125 \mathrm{~cm})$ with 20 floral buds retention increased to the maximum of 123.67, 134.5, 126, 126.6 and $129.6 \mathrm{~cm}$ accordingly with retaining 8 floral buds on the okra plants for seed production (Figure 1). The vegetative growth of the different varieties is governed by genetic factors as well as cultural practices [26]. Although the okra plants require optimum nutrition and moisture for maximum yield and production [27], however, the genetic 
potential of a variety is of paramount importance for growth and yield [28]. The increase in plant height with 8 floral buds left for seed production was the highest $(13.77 \%)$ in Sabz Pari variety and the least $(4.6 \%)$ in Green Star variety. The plant height in okra variety Arka Anamika was $5.7 \%$ higher with 8 floral buds as compared to 20 floral buds. Since, the variety Arka Anamika has been well known for its greater nutrient uptake and resistant to various pests and diseases that results in superior growth and yield $[5,8,29]$. Thus, the superior performance of Arka Anamika variety of okra is in line with the earlier findings $[30,31]$.

\section{Number of branches plant ${ }^{-1}$}

The number of branches per plant varied significantly among various varieties of okra and the number of floral bubs retained for seed production. The highest number of branches per plant (2.04) was recorded in Arka Anamika, followed by Pusa Sawani (1.95). The number of branches in Punjab Selection (1.85) and Sabz Pari (1.83) varieties were significantly higher than variety Green Star, which had the lowest (1.69) number of branches per plant (Table $1)$.

The number branches per plant increased significantly with decreasing the number of floral buds for seed production. The least mean number of branches per plant (1.68) were noted in 20 floral buds retention that increased to 1.75 with 14 floral buds, with the difference being non-significant. However, further decrease in the number of floral buds resulted in significant increase to 2.03 and 2.16 branches per plants with 11 and 8 floral buds retention for seed production (Table 1).

\section{Number of leaves plant $\mathbf{t}^{-1}$}

Number of leaves per plant varied widely as the variety Sabz Pari had the highest number of leaves (39.88), followed by Punjab Selection (37.87), Arka Anamika (35.79) and Green Star (35.80) respectively, whereas, Pusa Sawani plants had minimum (34.64) number of leaves per plant (Table 1).

\section{Number of seeds pod ${ }^{-1}$}

The number of seeds pod per pod data indicated significant variations among okra varieties. The highest number of seed pod per pod were recorded in Arka Anamika (65.30), followed by Sabz Pari (63.76) that were statistically at par with each other. The minimum number of seeds per pod (55.89) was recorded in variety Pusa Sawani (Table 2 ). The number of seeds per pod was significantly influenced by the number of floral buds retention for seed production. The minimum number of seeds pod $^{-1}$ (57.73) with 17 floral buds recorded and were at par with 20 floral buds (57.85) but increased significantly to 65.49 and 69.72 with decreasing the number of floral buds per plant to 11 and 8 . The interaction effect was also significant. The minimum numbers of seeds per pod were recorded in all the varieties with 20 floral buds retained for seed production (Figure 2). However, the number of seeds per pod increased significantly with decreasing the number of floral buds retained for seed production. Maximum number of seeds per pod was recorded in Sabz Pari (73.95), Arka Anamika (74.9), Pusa Sawani (63.84), Punjab selection (66.76) and Green Star (68.65) with 8 floral buds retained for seed production (Figure 2). It has been reported that removal of early formed fruit increased the number of seeds formed per fruit [32]. 
Table 1. Plant height $(\mathrm{cm})$, number of branches plant ${ }^{-1}$ and number of leaves plant ${ }^{-1}$ in various okra varieties as affected by floral buds retention

\begin{tabular}{|c|c|c|c|}
\hline Okra Varieties & Plant height (cm) & Branches plant $^{-1}$ & Leaves plant $^{\mathbf{1}}$ \\
\hline Sabz Pari & $118.99 \mathrm{e}$ & $1.83 \mathrm{~b}$ & $39.88 \mathrm{a}$ \\
\hline Arka Anamika & $131.65 \mathrm{a}$ & $2.04 \mathrm{a}$ & $35.79 \mathrm{c}$ \\
\hline Pusa Sawani & $124.72 \mathrm{c}$ & $1.95 \mathrm{ab}$ & $34.64 \mathrm{c}$ \\
\hline Punjab Selection & $122.29 \mathrm{~d}$ & $1.85 \mathrm{~b}$ & $37.87 \mathrm{~b}$ \\
\hline Green Star & $128.71 \mathrm{~b}$ & $1.64 \mathrm{c}$ & $35.8 \mathrm{c}$ \\
\hline LSD $(\mathrm{P} \leq 0.05)$ & 1.32 & 0.164 & 1.26 \\
\hline \multicolumn{4}{|c|}{ Floral Buds Retained } \\
\hline 8 & $128.07 \mathrm{a}$ & $2.16 \mathrm{a}$ & 36.55 \\
\hline 11 & $126.68 \mathrm{~b}$ & $2.03 \mathrm{a}$ & 36.59 \\
\hline 14 & $126.11 \mathrm{bc}$ & $1.75 \mathrm{~b}$ & 37.35 \\
\hline 17 & $125.23 \mathrm{c}$ & $1.69 \mathrm{~b}$ & 37.13 \\
\hline 20 & $120.26 \mathrm{~d}$ & $1.68 \mathrm{~b}$ & 36.36 \\
\hline LSD $(\mathrm{P} \leq 0.05)$ & 1.3201 & 0.1641 & 1.2582 \\
\hline \multicolumn{4}{|c|}{ Interactions } \\
\hline Varieties $\times$ floral buds & $* *$ & $\mathrm{~ns}$ & $\mathrm{n}$ \\
\hline
\end{tabular}

Means followed by similar letters are non-significant at $\mathrm{p} \leq 0.05$

\section{Hundred seed weight $(\mathrm{g})$}

Significant variations were recorded for hundred seed weight among the okra varieties. Pusa Sawani had the highest seed weight $(7.55 \mathrm{~g})$, followed by Arka Anamika $(7.48 \mathrm{~g})$, with the difference being nonsignificant. Minimum seed weight $(6.86 \mathrm{~g})$ was recorded in variety Sabz Pari (Table 2). The seed weight decreased significantly with increasing the number of floral buds for seed production. Minimum seed weight (6.91 g) was observed when 20 floral buds were left for seed production. However, seed weight increased significantly to 7.6 and $7.76 \mathrm{~g}$ with decreasing the number of floral buds to 11 and 8 respectively (Table 2 ).

\section{Seed weight pod $^{-1}$}

Arka Anamika had maximum seed weight per pod (4.29 g) followed by Green Star (3.99 g), Sabz Pari (3.89 g) and Pusa Sawani (3.80 g). The minimum seed weight per pod (3.51 g) was found in Punjab Selection (Table 2). The number of floral buds kept for seed production significantly affected the seed weight per pod. The seed weight per pod was the least $(2.34 \mathrm{~g})$ with 20 floral buds retention, which increased non-significantly to $2.64 \mathrm{~g}$ with 17 floral buds. However, decreasing the number of floral buds further to 14,11 and 8 buds resulted in significant increase in the seed weight per pod to 3.69 , 5.12 and $5.68 \mathrm{~g}$ accordingly.
Seed yield ( $\left.\mathrm{tha}^{-1}\right)$

Maximum seed yield (2.37 $\left.\mathrm{t} \mathrm{ha}^{-1}\right)$ was recorded in variety Arka Anamika, followed by Green Star $\left(2.10 t^{~ h a} a^{-1}\right)$. The varieties Sabz Pari and Pusa Sawani stood in the middle with 2.32 and $1.98 \mathrm{t} \mathrm{ha}^{-1}$ of seed yield and were at par with each other, while the minimum seed yield of $1.83 \mathrm{t} \mathrm{ha}^{-1}$ was recorded in Punjab Selection (Table 2). Seed yield per hectare was maximum $\left(2.77 \mathrm{t} \mathrm{ha}^{-1}\right)$ with 20 floral buds, which decreased significantly to 2.23 and $1.90 \mathrm{t} \mathrm{ha}^{-1}$ by decreasing the number of floral buds for seed production to 17 and 14 . The seed yield decreased further to $1.88 \mathrm{t} \mathrm{ha}^{-1}$ with 11 floral buds and finally to the minimum of $1.51 \mathrm{t} \mathrm{ha}^{-}$ ${ }^{1}$ when 8 floral buds were retained for seed production (Table 2). Interaction effect was also significant. Maximum seed yield in all the okra varieties was observed with retention of 20 floral buds for seed production. Seed yield decreased with decreasing the number of floral buds and minimum seed yield of different okra varieties were with 8 floral buds retained for seed production (Figure 3 ). It can be stated that the earlier pods developed increase the sink activity and pods removal decreases the powerful sinks that allow optimum allocation of nutrient for vegetative and reproductive growth [14]. The interaction of floral buds retention and okra varieties revealed that the yield was significantly 
reduced with decreasing the number of pods per plant. However, the maximum decline in seed yield $(54.77 \%)$ was in variety Arka Anamika and minimum (39.22\%) in Sabz Pari variety. By contrast, the increase in number of floral buds retained for seed production decreased the number of seeds per pods, seed weight per pod, 100 seed weight and yield. Since the flower and fruit in okra plant exert a strong sink activity on subsequent flowers and fruits, retaining large number of floral buds is likely to decrease the seed quality characteristics $[26,33]$.

Hard seed (\%)

The hard seed percentage was not significantly affected among the different okra varieties under study. However it was significantly affected by the number of floral buds retention. The hard seed percentage ranged from 20.13 to 20.87 in different okra varieties (Table 2). Highest hard seed percentage $(26.77 \%)$ was recorded in okra plants with 20 floral buds retained for seed production, which decreased significantly to 25.18 and $19.71 \%$ with decreasing the number of floral buds for seed production to 17 and 14. The hard seed percentage further decreased to 16.86 and $14.18 \%$ respectively with 11 and 8 floral buds retained for seed production (Table 2). The hardseedness is an undesirable characteristic of okra seed, which resulting in lack of uniformity and total or partial failure in seed germination [34]. The seed most suited for storage may have moisture content not greater than 10 percent of the seed weight [35]. Reducing the moisture content below 8 percent may enhance hard seed development [36]. The hardseedness induces a physical dormancy due to its suberized seed coats that are not permeable to water and hence does not allow proper hydration of the seed [37]. The okra varieties evaluated in this study showed no significant variation in hardseed percentage but it was significantly affected by increasing the number of floral buds on the plant for seed production. It has been reported earlier that hardseeds becomes more common in okra when the pods remain on the plant for longer than desired duration [38], probably due to excessive loss of moisture [23]. It is suggested that harvesting the seeds with high moisture content decrease the hardseedness in okra [39]. The increased highest hardseed percentage with 20 floral buds may be due to greater time to seed harvest or poor seed maturation at the later part of the season [17].

Table 2. Number of seeds $\operatorname{pod}^{-1}$, seed weight $\operatorname{pod}^{-1}(\mathrm{~g}), 100$ seed weight $(\mathrm{g})$ seed yield $\left(\mathrm{t} \mathrm{ha}^{-1}\right)$ and hard seed $(\%)$ of various okra varieties as affected by floral buds retention

\begin{tabular}{|c|c|c|c|c|c|}
\hline Okra Varieties & Seeds pod $_{1}^{-}$ & $\begin{array}{l}100 \text { seed } \\
\text { weight }(\mathrm{g})\end{array}$ & $\begin{array}{l}\text { Seed weight } \\
\operatorname{pod}^{-1}(\mathrm{~g})\end{array}$ & $\begin{array}{c}\text { Seed yield }(t \\
\left.h^{-1}\right)\end{array}$ & Hard seed $(\%)$ \\
\hline Sabz Pari & $63.76 \mathrm{a}$ & $6.86 \mathrm{c}$ & $3.89 \mathrm{bc}$ & $2.00 \mathrm{bc}$ & 20.49 \\
\hline Arka Anamika & $65.30 \mathrm{a}$ & $7.48 \mathrm{a}$ & $4.29 \mathrm{a}$ & $2.37 \mathrm{a}$ & 20.87 \\
\hline Pusa Sawani & $55.89 \mathrm{c}$ & $7.55 \mathrm{a}$ & $3.80 \mathrm{c}$ & $1.98 \mathrm{c}$ & 20.52 \\
\hline Punjab Selection & $61.71 \mathrm{~b}$ & $6.99 \mathrm{c}$ & $3.51 \mathrm{~d}$ & $1.83 \mathrm{~d}$ & 20.66 \\
\hline Green Star & $62.87 \mathrm{~b}$ & $7.3 \mathrm{~b}$ & $3.99 \mathrm{~b}$ & $2.10 \mathrm{~b}$ & 20.13 \\
\hline $\operatorname{LSD}(\mathrm{P} \leq 0.05)$ & 1.542 & 0.1755 & 0.159 & 0.091 & ns \\
\hline \multicolumn{6}{|c|}{ Floral Buds Retained } \\
\hline 8 & $69.72 \mathrm{a}$ & $7.76 \mathrm{a}$ & $5.68 \mathrm{a}$ & $1.51 \mathrm{e}$ & $14.18 \mathrm{e}$ \\
\hline 11 & $65.49 \mathrm{~b}$ & $7.6 \mathrm{a}$ & $5.12 \mathrm{~b}$ & $1.88 \mathrm{~d}$ & $16.83 \mathrm{~d}$ \\
\hline 14 & $61.73 \mathrm{c}$ & $6.98 \mathrm{~b}$ & $3.69 \mathrm{c}$ & $1.90 \mathrm{c}$ & $19.71 \mathrm{c}$ \\
\hline 17 & $57.73 \mathrm{~cd}$ & $6.94 \mathrm{~b}$ & $2.64 \mathrm{~d}$ & $2.23 \mathrm{~b}$ & $25.18 \mathrm{~b}$ \\
\hline 20 & $57.85 \mathrm{~d}$ & $6.91 \mathrm{~b}$ & $2.34 \mathrm{~d}$ & $2.77 \mathrm{a}$ & $26.77 \mathrm{a}$ \\
\hline $\mathrm{LSD}(\mathrm{P} \leq 0.05)$ & 1.542 & 0.1755 & 0.159 & 0.091 & 0.807 \\
\hline \multicolumn{6}{|c|}{ Interactions } \\
\hline Varieties $\times$ Flo & 1 buds * & ns & ns & $*$ & ns \\
\hline
\end{tabular}

Means followed by similar letters are non-significant at $\mathrm{p} \leq 0.05$ 


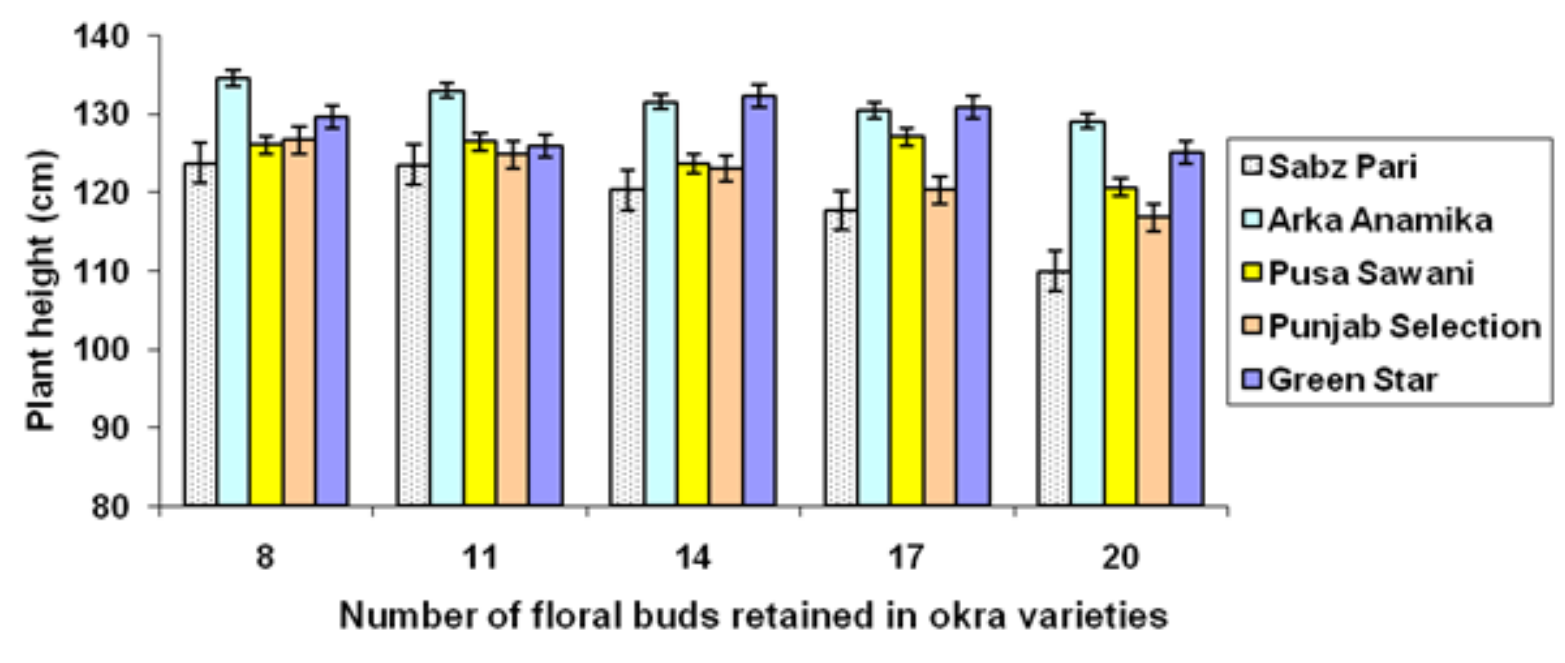

Figure 1. Interaction effect of floral buds retention and okra varieties on the plant height. The vertical error bars represent standard error at $p \leq 0.05$

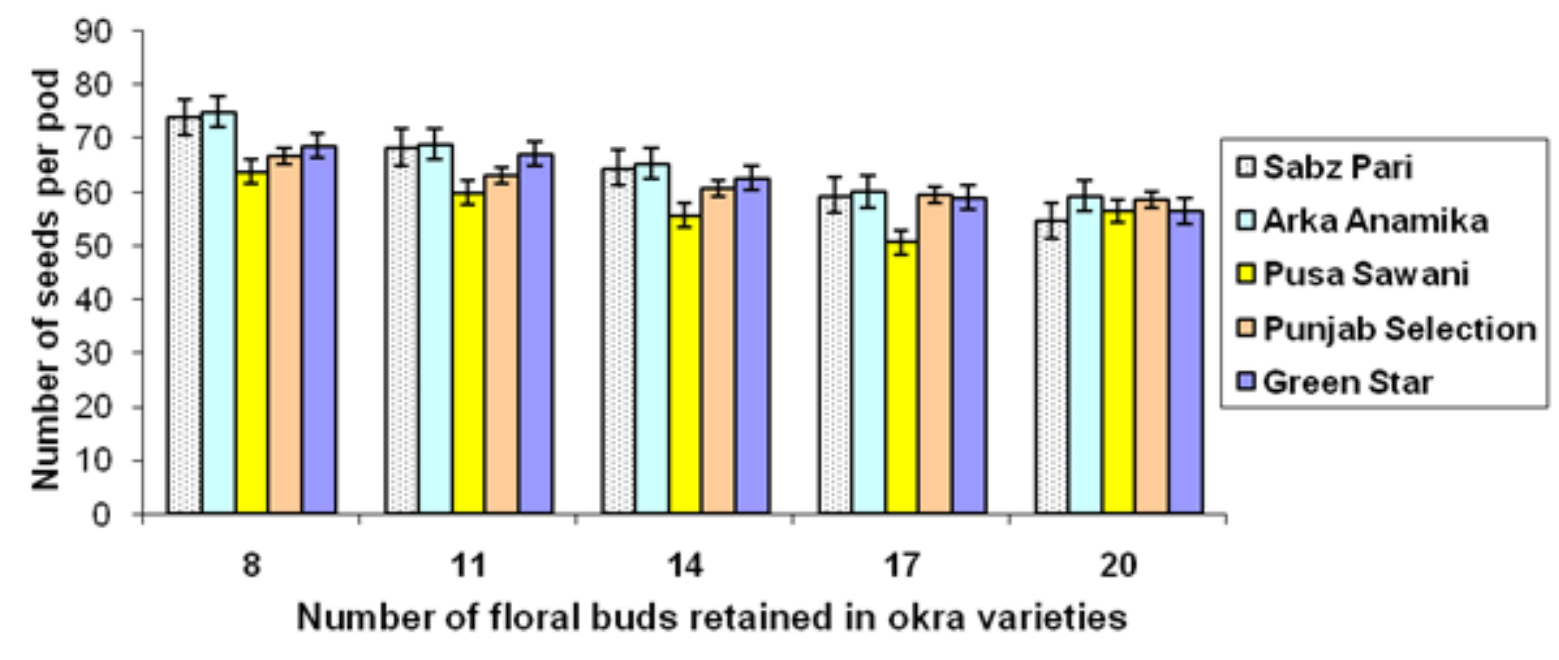

Figure 2. Interaction effect of floral buds retention and okra varieties on the number of

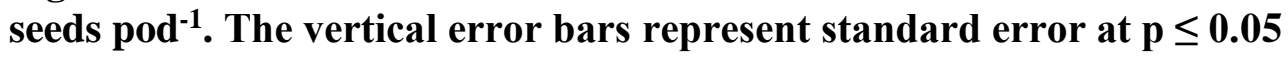




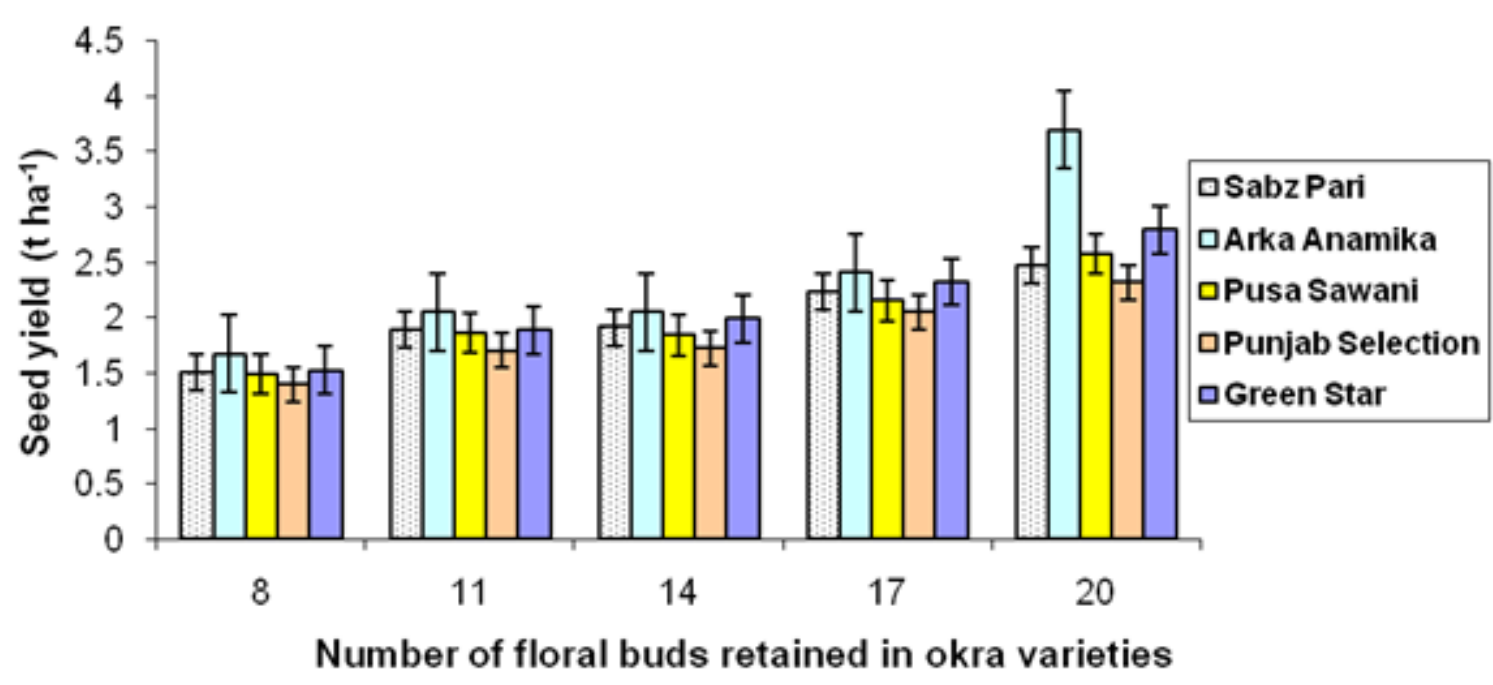

Figure 3. Interaction effect of floral buds retention and okra varieties on the seed yield. The vertical error bars represent standard error at $\mathbf{p} \leq \mathbf{0 . 0 5}$

\section{Conclusion}

It can be concluded from the experimental results that the okra varieties differ significantly in vegetative and reproductive growth. Variety Arka Anamika was the most superior in all the varieties under study in plant height, number of branches per plant and also produced the maximum number of seeds per pod with the highest seed weight per pod and maximum seed yield. The number of floral buds retained for seed production significantly affected the vegetative growth and okra seed production. Although retaining 8 buds per plant resulted in the maximum plant height, but decreased the number of branches per plant, number of seeds per pod, seeds weight per pod and hundred seed weight. Despite declining the seed yield, it reduced the hardseed percentage to the minimum. By contrast, plants with 20 buds retained for seed production resulted in the maximum yield as well as hardseed percentage. Thus, the seed yield and quality may be considered as a compromise and the retention of 14 to 17 floral buds for seed production can be recommended due to modest decrease in yield but improving the quality attributes such as number of seeds per pod, seed weight per pod and hundred seed weight as well as minimizing the hardseed percentage.

\section{Authors' contributions}

Conceived and designed the experiments: MA Khan \& A Rab, Performed the experiments: MA Khan, Analyzed the data: MA Khan \& A Rab, Contributed materials/ analysis/ tools: MA Khan, Wrote the paper: MA Khan.

\section{References}

1. Oyelade OJ, Ade-Omowaye BIO \& Adeomi VF (2003). Influence of variety on protein, fat contents and some physical characteristics of okra seeds. J Food Eng 57(2): 111-114.

2. Hassan MA \& Ali HM (2015). The nutritional composition of three cultivars of okra (Abelmoschus esculentus L.) seeds flour. World $J$ Dairy Food Sci 10(2): 122-131.

3. Moosavi SA, Aghaalikhani M, Ghobadian B \& Fayyazi E (2018). Okra: A potential future bioenergy crop in Iran. Renewable and Sustainable Ener Rev 93: 517-524.

4. Tiamiyu RA, Ahmed HG \& Muhammad AS (2012). Effect of sources of organic manure on growth and yields of okra (Abelmoschus esculentus L.) in Sokoto, Nigeria. Niger J Basic Appl Sci 20(3): 213-216. 
5. Ayyaz M, Nadeem M \& Begum HA (2017). Screening of okra varieties resistance against insect pests under agro climatic conditions of Dera Ismail Khan, Pakistan. Russ Agr Sci 43(2): 149-152.

6. Eshiet AJ \& Brisibe EA (2014). Morphological characterization and yield traits analysis in some selected varieties of okra (Abelmoschus esculentus L. Moench). Adv Crop Sci Technol: 1-5.

7. Solangi AM, Siyal AG, Soothar RK \& Shah AR. (2015). Nutrient uptake of some okra varieties as influenced by different levels of applied N, P and K. Sci Int 27(5): 4327-31.

8. Elhag AZ \& Ahmed A A. (2014). Effect of Cultivar and Sowing Date on Okra (Abelmoschus esculentus L. Moench) Seed Yield. Univer J Appl Sci 2(3): 64-67.

9. Madisa ME, Mathowa T, Mpofu C \& Oganne TA (2015). Effects of plant spacing on the growth, yield and yield components of okra (Abelmoschus esculentus L.) in Botswana. Am J Exp Agric 6(1): 7-14.

10. Ahamed KU, Akter B, Ara N, Hossain MF \& Moniruzzaman M (2015). Heritability, correlation and path coefficient analysis in fifty seven okra genotypes. Int J Appl Sci Biotech 3(1): 127-133.

11. Maurya RP, Bailey JA \& Chandler JSA (2013). Impact of plant spacing and picking interval on the growth, fruit quality and yield of okra (Abelmoschus esculentus L.). Am J Agric Fores 1(4): 48-54.

12. Reddy MT, Pandravada SR, Sivaraj NA, Sunil NE, Dikshit NI, Kamala VE (2017). Backyard Farming of Okra (Abelmoschus esculentus L. Moench) in Traditional Agricultural Landscapes of Adilabad District, Telangana, India. J Glob Agric Ecol 6:147-61.

13. Meena VK, Dubey AK, Jain VK, Tiwari A \& Negi P (2017). Effect of plant growth promoters on flowering and fruiting attributes of okra (Abelmoschus esculentus L. Moench). Field Crop Res 52(1): 2.

14. Bhatt RM \& Rao NS (1997). Sourcesink relationship in Abelmoschus esculentus L. Biol Plantarum 39(2): 223-228.

15. Bhatt, RM \& Rao NKS (1993). Photosynthesis and dry matter distribution as influenced by reproductive sink manipulation in okra (Abelmoschus esculentus L.). Indian J Plant Physl 36: 25-27.

16. Nataraj SE, Kulkarni GN, Vyakaranahai BS \& Shasidhara SD (1992). Effect of nitrogen levels and picking fresh fruits on seed quality of okra (Abelmoschus esculentus L.). Karnataka J Agic Sci 5(1): 51-53.

17. Setubal JW, Zanin ACW \& Nakagawa $\mathrm{J}$ (1994). Effects of harvesting methods and fruit position in plant on hard seed occurrency in okra (Abelmoschus esculentus L.). Sci Agr 51(3): 490-493

18. Khan AR \& Jaisal RC (1988). Effect of nitrogen, spacing and green fruit pickings on the seed production of okra (Abelmoschus esculentus L. Moench). Vegetable Sci 15(1): 8-14.

19. Moniruzzaman M, Uddin MZ \& Choudhury AK (2007). Response of okra seed crop to sowing time and plant spacing in south eastern hilly region of Bangladesh. Bangladesh J Agric Res 32(3): 393-402.

20. Nabi A, Sharma SK \& Shukla YR (2009). Effect of fruit load on seed yield and quality of okra. Ann Biol 25(2): 147-149.

21. Narayan S, Ahmed N, Shahnaz M, Afroza B, Roohi S \& Hussain K (2009). Effect of fruit load on quality and seed yield in okra (Abelmoschus esculentus L.) under temperate conditions of Kashmir valley. Asian $J$ Hort 4(1): 57-58.

22. Musara C, Chitamba J \& Nhuvira C. (2015). Evaluation of different seed dormancy breaking techniques on okra (Abelmoschus esculentus L.) seed 
germination. Afr J Agric Res 10(17): 1952-1956.

23. El-Balla MMA, Said A \& Makkawi M (2011). Effect of moisture content and maturity on hardseededness and germination in okra (Abelmoschus esculentus L.). Int J Plant Physiol Biochem 3(6):102-107.

24. Auld DL, Bettis BL, Crock JE \& Kephart D (1988). Planting data and temperature effects on germination, and seed yield of chickpea. Agron J 80: 909-914.

25. Steel RGD \& Torrie JH (1984). Principles and procedures of statistics. International Student ed.

26. Nabi A, Sharma SK \& Shukla YR (2010). Effect of fruit load on morphological characters and yield in okra. Ann Agric Biol Res 15(1): 17-19.

27. Kumar V, Saikia J \& Nath DJ (2017). Effect of integrated nutrient management on growth, yield, and quality of okra (Abelmoschus esculentus L. Moench) cv. Arka Anamika. IJCS 5(5): 2001-2003.

28. Mohammed IG, Osipitan AA, Pitan AA \& Atayese M (2013). Evaluation of 15 varieties of okra (Abelmoschus esculentus L. Moench) to field infestation by Flea Beetles (Podagrica spp.). Afr Entomol 21(1): 70-78.

29. Solangi M, Tagar AA, Solangi AM, Siyal AG, Soothar RK \& Shah AR (2015). Nutrient uptake of some okra varieties as influenced by different levels of applied N, P and K. Sci Inter 27: 4327-4331.

30. Ullah S, Javed H \& Aziz MA (2012). Role of physico-morphic characters of different okra genotypes in relation to population of Jassid, Amrasca biguttula, Biguttula ishida. J Agric Res 50(2): 217224.
31. Harishchand R, Khan MM \& Singh PK (2013). Effect of spacing and cultivars on growth and yield of okra (Abelmoschus esculentus L. Moench). Asian J Hortic 8(2): 507-511.

32. Moniruzzaman M, Uddin MZ \& Choudhury AK (2007). Response of okra seed crop to sowing time and plant spacing in south eastern hilly region of Bangladesh. Bangladesh J Agric Res 32(3): 393-402.

33. Bhatt RM \& Rao NKS (2009). Physiology, crop growth, development and yield. In Dhankhar, B.S., Singh, R. (eds.): Okra Hand Book, Okra Hand Book, Global Production, Processing and Crop Improvement. HNB Publishing, New York. pp 37-60.

34. Castro MM (2005). Qualidade fisiológica de sementes de quiabeiro emfunção da idade e do repousopóscolheita dos frutos. M. Sc thesis. Botucatu: FCA, UNESP. pp 43.

35. Mohammadi, G., \& AVAL, M. B. (2011). Differential responses for harvesting times and storage on hardness of different varieties of okra. Not Sci Biol 3(4): 117-122.

36. Dhankhar BS, Singh R (2009). Okra handbook, global production, processing and crop improvement. (No. 635.648/D533). HNB publishing.

37. Hudson AR, Ayre DJ \& Ooi MK (2015). Physical dormancy in a changing climate. Seed Sci Res 25(2): 66-81.

38. Mohammadi G \& Aval MB (2011). Differential responses for harvesting times and storage on hardness of different varieties of okra. Not Sci Biol 3(4): 117-122.

39. Demir I (1997). Occurrence of hardseededness in relation to seed development in okra (Abelmoschus esculentus L.). Plant Var Seeds 10: 713 